\title{
The development of unconsolidated sedimentary coastal cliffs (Pobrzeże Kaszubskie, Northern Poland)
}

\author{
Grzegorz UŚCINOWICZ1 ${ }^{1, *}$, Leszek JURYS ${ }^{1}$ and Tomasz SZARAFIN ${ }^{1}$
}

1 Polish Geological Institute - National Research Institute, Marine Geology Branch, Kościerska 5, 80-328, Gdańsk, Poland

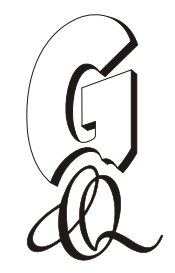

\begin{abstract}
Uścinowicz, G., Jurys, L., Szarafin, T., 2017. The development of unconsolidated sedimentary coastal cliffs (Pobrzeże Kaszubskie, Northern Poland). Geological Quarterly, 61 (2): 491-501, doi: 10.7306/gq.1351

In the course of fieldwork based on geological and landslide mapping and spatial analyses of map information at least 2 types of landslides were identified. Type I: simple landslides developed in homogeneous and undisturbed rocks, for instance - loams, clays and sands. This type of landslide includes many examples developed mainly on the stretch (segment of the studied area) approximately between 132.25 and $133.50 \mathrm{~km}$ and 128.50 and $129.50 \mathrm{~km}$ of the Polish coastline. Type II: complex landslides in which the movement and displacement of rock masses occurs under complex geological and hydrogeological conditions. The complex factors are determined by phenomena such as glaciotectonics, discontinuities of rock layers and thrust zones; the slip surface occurs at considerable depths, and sometimes several slip surfaces can be distinguished. These landslide types are located in the vicinity of Jastrzębia Góra and Rozewie, near km 134 and 131.5. Prediction of the formation of this landslide types is difficult. Even if long-term observations are available, the mass movement variable over time, is difficult to interpret. It is clear that the changes are continuous, but occur with varying intensity. Proper recognition of the types of mass movement is crucial to establishing the appropriate methods to prevent their development.
\end{abstract}

Key words: cliff coast, landslides, soft sediments, southern Baltic.

\section{INTRODUCTION}

Coastal areas have always been important for economic and social reasons. They are subject to pressure from settlements and (still) are an important part of socio-economic development. Therefore, special attention should be paid to the risks arising from a specific feature of the contact between marine and land environments. Among all types of coasts, the greatest natural hazards are linked with steeply cliffed coasts, where landslides of various dimensions, nature and genesis are often developed. (Eurosion, 2004; Lee, 2008; Montoya-Montes et al., 2012; Hackny et al., 2013; Carpenter et al., 2014; Kuhn and Prufer, 2014; Young et al., 2014). Large landslides, active over many years, create particular hazards.

Marine erosion and mass movements belong to the main geodynamic processes shaping the coasts of the sea around the globe. These processes are generated by many interrelated factors such as geology and geomorphology, hydrological conditions, hydrogeological and hydrodynamic factors (drainage of groundwater due to the proximity to the sea), and anthropogenic and climatic phenomena (Varnes, 1978; Cruden and Varnes, 1996; Dikau and Schrott, 1999; Fiorillo, 2003; Della Seta et al., 2013; Hungr et al., 2014; Kuhn and Prufer, 2014;

* Corresponding author, e-mail: grzegorz.uscinowicz@pgi.gov.pl

Received: October 25, 2016; accepted January 20, 2017; first published online: March 20, 2017
Kostrzewski et al., 2015; Mickovski et al., 2015; Young et al., 2016; Joyal et al., 2016). In various combinations, these factors lead to the development of mass movements which may initially seem harmless, and then become a significant problem through the continuous development. Predicting the places and time of their formation is extremely difficult (Pellicani et al., 2013; Lari et al., 2014). Even with long-term observations, the movement of rock masses is variable in time and challenging to interpret. It is clear, though, that the changes are continuous, although occurring with various intensity and by various mechanisms.

The characteristics of these phenomena and attempts to prevent their development are particularly difficult in complex geological conditions, which can include interbedding of cohesive and non-cohesive rocks (glacial tills, silts and clays, glaciofluvial sands and gravel such as), while the continuity of sedimentary successions is often disrupted by glacitectonic structures. The occurrence of landslides in this type of succession has been widely discussed (Dickson et al., 2007; Lee, 2008; Carpenter et al., 2014).

Such conditions can be often found on the Polish Baltic coast. Intense geodynamic processes have been reported particularly around the Kaszuby Coast, in the vicinity of Jastrzębia Góra, Rozewie and Władysławowo (Subotowicz, 1982, 1995a, b; Uścinowicz et al., 2004; Ilcewicz-Stefaniuk et al., 2005). These processes have been described both for scientific and more practical reasons, the latter aiming at stabilizing the arising landslides. Research has been focused on marine erosion as a major causative factor, via waves and storm surges and to a lesser extent on the identification of geological and 


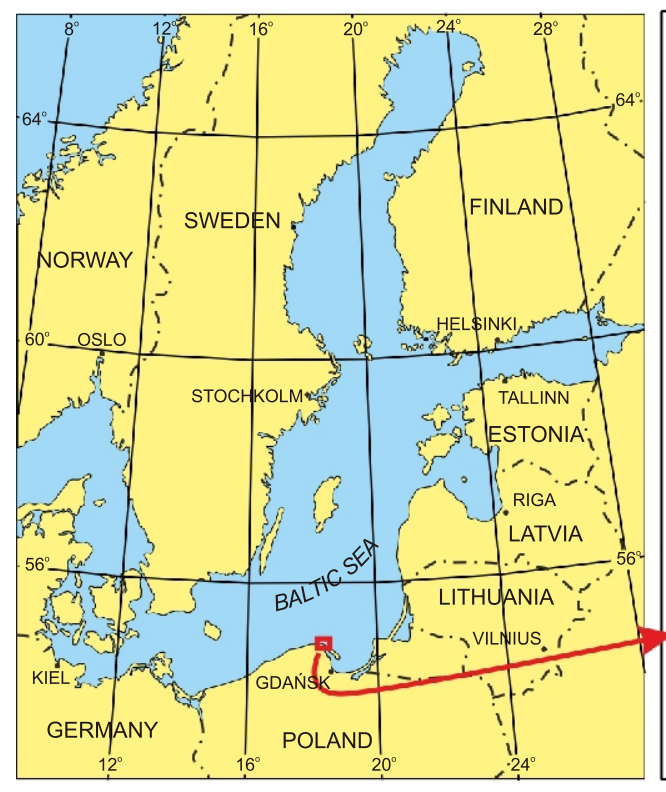

$18^{\circ} 17^{\prime} \mathrm{O}^{\prime \prime E}$

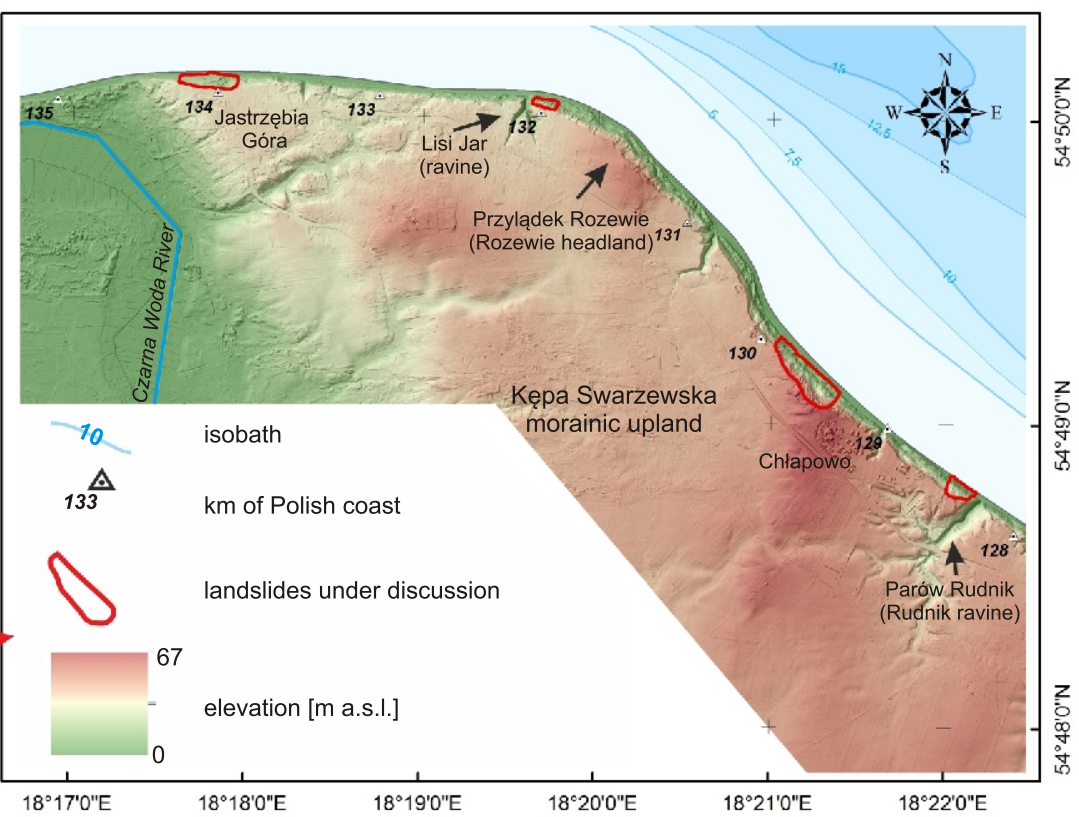

Fig. 1. Location of the study area hydrogeological factors including the inflow of groundwater into the sea. It is generally assumed that the marine erosion destroys the foot of the cliff (at a rate dependent on the vulnerability of rock), waves remove talus or colluvial material, the slope is again undercut beyond the threshold of stability and landslides occur. However, the observations made on the Polish coast revealed that, despite protection of the base of the cliffs, which should potentially halt erosion, landslides continue to evolve and, in some cases, the rate of deformation increases. This led the authors to a more complex approach to these issues, drawing attention to the importance of the relationship between the geological structure (of both the onshore and offshore part of the coast), hydrogeological conditions, marine erosion and human activities. The main scientific focus was overall analysis of the geological structures occurring on land and continuing offshore and under the seabed. This enabled the observation of some areas where mass movements occur and create extensive, active and periodically active landslides.

Therefore, the aim of this field-based study is to characterize the morphology and basic types of landslides developed in unconsolidated deposits of this part of the coast, as well as to describe their inferred controls.

\section{STUDY AREA}

The study area is located in the northernmost part of Poland and covers an area of morainic upland, the Kępa Swarzewska (Fig. 1). The upland is slightly elongated from NNW to SSE. It borders with the Baltic Sea to the north and east (to the east through the Gulf of Gdańsk); to the west and in the south it is limited by the large Płutnica and Czarna Woda River valleys. The section of coast studied stretches over a distance of $\sim 7.5 \mathrm{~km}$ and is located between the resorts of Jastrzębia Góra and Władysławowo - between 127.0 and $134.5 \mathrm{~km}$ of the Polish coastline. The coastline in the west is similar to the latitudinal and turns to the SE in the vicinity of Rozewie headland ( $132 \mathrm{~km}$ of the Polish coast). The cliff coast in the area under discussion reaches a height from a dozen of metres to $67 \mathrm{~m}$. The edge of the upland is dissected by deep erosional ravines in several places. It extends down to sea level and some structures (e.g., Lisi Jar) have their palaeocontinuation under the seabed. The edge of the upland is almost completely free of watercourses. Only periodically are the ravines partly filled with water which flows to the sea or infiltrates into the beach sand.

The oldest deposits cropping out in the upland are of Miocene age (Kramarska, 1999; Wagner, 2007). These are mainly silts, in places with lignite, and fine to medium grained sands. The top of the Miocene succession is variable and lies $17 \mathrm{~m}$ below sea level [b.s.l] in the west. However, in the eastern and central part, it is exposed in the cliff face at $15-17 \mathrm{~m}$ above sea level [a.s.l.]. The Miocene strata are overlain by Pleistocene deposits (Fig. 2).

There are three levels of till interbedded with sandy deposits and clays, exposed in the western part of the cliff (Masłowska et al., 2002; Uścinowicz et al., 2014). Glaciotectonic structures were visible in the western, edge part of the upland. The lower part of the cliff profile is built of grey till which has been assigned to the Saalian Glaciation. In the central part of the cliff there is a consistent level of till with a maximum thickness of $20 \mathrm{~m}$ - this was assigned to the Middle Stadial of the Weichselian Glaciation. The uppermost, youngest level of till is 5-6 m thick. It is very sandy with small quantities of gravel. Marginal lacustrine deposits occur locally. Silts and clays are exposed in the cliff at Jastrzębia Góra at heights ranging between $15 \mathrm{~m}$ a.s.l. and $2 \mathrm{~m}$ b.s.l. The eastern part of this cliff has a much simpler geological structure. The lowermost part of the cliff is built of sands and silts, locally with lignite of Miocene age. Directly above these, glaciofluvial and glacial sands and gravels occur. These sands are overlain by a discontinuous layer of glacial till of the Weichselian Glaciation. Locally, the surface of the morainic upland is covered by aeolian sands. The thickness of this cover is up to $3 \mathrm{~m}$. It should be noted that in this part of the coast the Neogene/Pleistocene boundary is of erosive character, with an associated boulder and gravel layer over almost the entire distance.

The seabed within the study area gradually declines to the north and north-east. Isobaths of $2.5 \mathrm{~m}, 5 \mathrm{~m}$ and $10 \mathrm{~m}$ are more or less parallel to the shore. There are two or occasionally three bars close to the shore. These are rather low, of between 0.5 

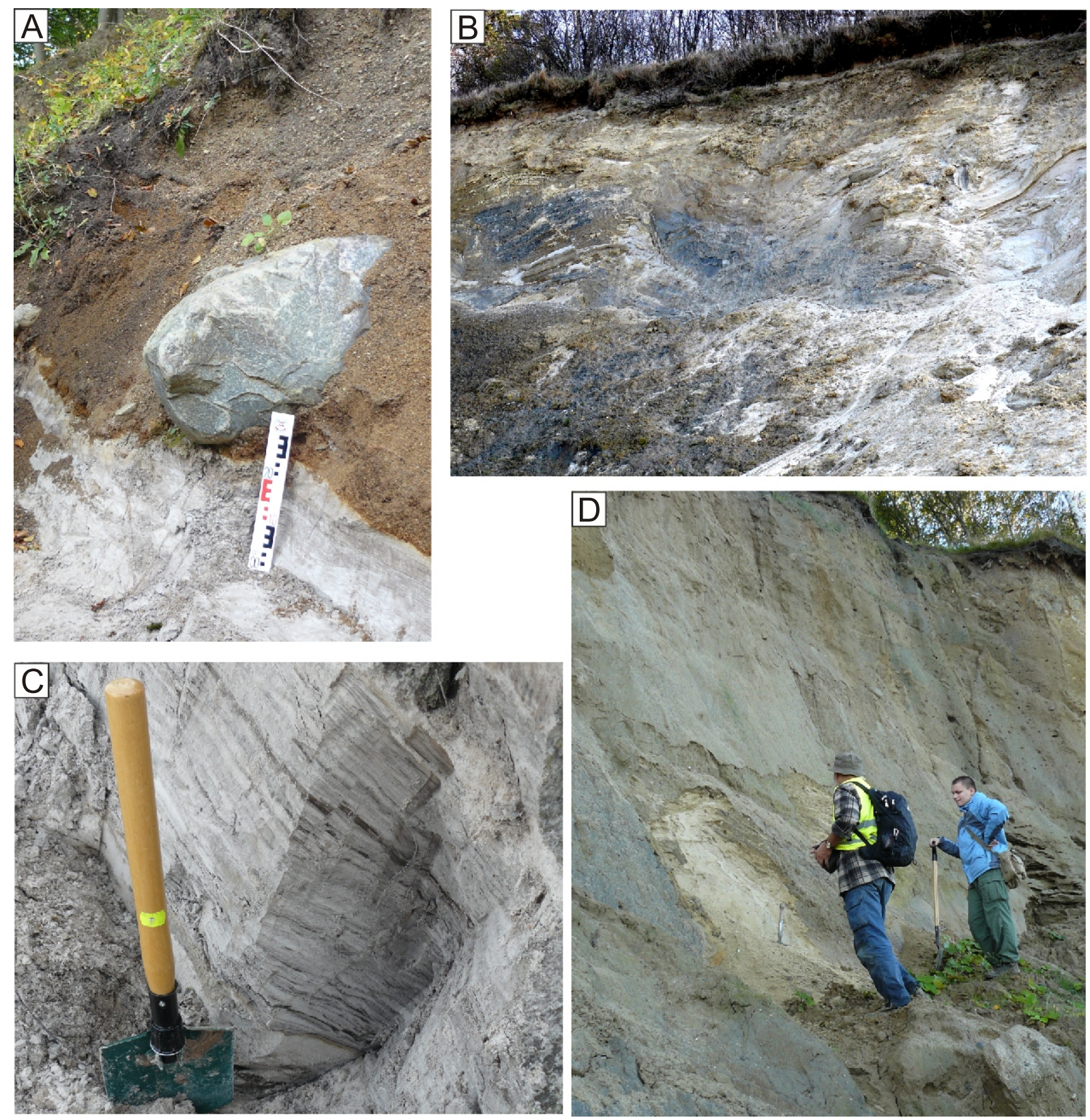

Fig. 2. Photos illustrating some characteristic features of the study area

A - Miocene (lower - light grey, silty sand)/Pleistocene (upper - sand with boulders) contact; B - deformed uppermost part of the cliff in the vicinity of Jastrzębia Góra; C - colluvium of the landslide (rotated complex of Miocene sand);

D - Weichselian till succession (uppermost part of the cliff)

and $2.5 \mathrm{~m}$ (Łęczyński, 2002; Zachowicz et al., 2007). The seabed is built mainly of fine-grained and silty sands of Holocene age. However, these sediments are often discontinuous and have a small thickness, so that the underlying Miocene strata, and locally glacitectonically deformed Oligocene(?) clays as well as Pleistocene tills are revealed in places (Zachowicz et al. 2007; Uścinowicz et al., 2014).

\section{MATERIAL AND METHODS}

The study was based on several types of analysis. First, spatial analyses were conducted on the oldest available maps German topographic maps from 1877-1910 (Topographische
Karte, 1877, 1910: 137-Ostrau; 138-Rixhof). The approximate coastline retreat was analysed based on this historical information and the modern situation (the coastline position in 2015 according to the Maritime Office). These old German maps are the only (but good) source of information concerning the coastal topography at the beginning of the 20th century, and comparison of these with modern maps is good enough to show the general evolution of the Polish Baltic coast.

Secondly, a digital terrain model [DTM] based on laser airborne scanning with a resolution of $1 \times 1 \mathrm{~m}$ was analysed using various geoprocessing techniques. Parameters affecting the vividness and readability of the digital model were adjusted. These parameters included colour scale, contrast and contours. The DTM was a basic source of information on the mor- 
phological parameters of the landslides and was used in the preparation of cross-sections of the cliff slope. Subsequently, analysis of the geological setting was made based on archival stored in the Central Geological Database as well as at the National Geological Archive and the HydroBank (database). This part of the study mainly involves analysis of the location of boreholes, of the thickness of the Quaternary succession and of the lithologies of both the Quaternary and the underlying strata. This enabled the selection of reliable archival data for further analysis.

However, the major method of data collection was fieldwork, as geological and geohazard (landslide) mapping. The area under discussion was visited tens of times between years 2012-2016 and as a result a detailed inventory of landslides was made. The methodology comprised: (1) field work-observation-interpretation, (2) repeated field work-observation-interpretation, and (3) comparison of recorded changes. This process was repeated several times so that the whole section of cliff was mapped. This systematic, regular work was necessary because significant sections of the cliff are covered with colluvial deposits and overgrown with plants. Nevertheless, during these methodical, long-term studies, it was possible to illustrate exposures which are periodically exposed by marine erosion. There is less information on the geological conditions in the offshore part of the study area.

Cartographic field work was focused mainly on cleaning exposure faces, photographically documentating and taking GPS measurements of landslides and associated coastal features. During the latest phase, the newly obtained data were analysed and compared with past data (e.g., of geological structure and field observations).

\section{RESULTS}

The complementary studies conducted have documented a continuous occurrence of mass movements at different scales - from the simple to genetically and morphologically complex forms. The mass movements have a repetitive pattern. Starting from the western end of the area, complex landslides alternate in space with simple landslides. The first kind occurs in the following sections: 134.5-133.5 km (Jastrzębia Góra area); $132.5-131.7 \mathrm{~km}$ (the area west of the Rozewie headland); 130.3-128 km (the area south-east of the Rozewie headland towards Chłapowo). A special case here is the area of the Rozewie headland, secured by hydrotechnical construction that kept the bluff stable and prevented further marine erosion, except for an incident in 2004 when there was a short-term renewal of landsliding. These areas are characterized by diverse conditions determining the kinds of emerging landslides. We describe below four landslides that are typical examples of simple and complex forms respectively, together with their associated processes, chosen from among the broad inventory of landslides mapped in the study area.

\section{RUDNIK LANDSLIDE 128.3-128.5 KM}

Map analysis shows that the coastline in the vicinity of the landslide shifted landward by $\sim 70 \mathrm{~m}$ in the west and $60 \mathrm{~m}$ in the east. The land retreat is $\sim 80 \mathrm{~m}$ in front of the landslide. The landslide north-west of ravine Rudnik is not shown on archived maps. A topographic map from 1910 shows the characteristic steep, aligned slope (Fig. 3A). However, it is adjacent to the area covered by landslides, which may suggest that this is a part of an older mass movement enlarging its spatial range.
The cliff reaches a height of $42 \mathrm{~m}$ a.s.I. and the landslide extends over a distance of $\sim 180 \mathrm{~m}$. Its total length is $\sim 60 \mathrm{~m}$, while the length of displaced mass is $40 \mathrm{~m}$. The main scarp of the landslide is $7 \mathrm{~m}$ high (Figs. 4 and 5). An interesting feature of this landslide is its incomplete development in comparison to the landslides discussed below. In particular, the landslide forms only the upper part of the cliff which is otherwise built of glaciofluvial deposits of Pleistocene age. The lower limit of the landslide (colluvium) reaches an elevation of $\sim 20 \mathrm{~m}$ a.s.I. Directly below, the slope is built of silty-, fine- and mediumgrained sands interbedded with Neogene silts and silty clays. However, there is some loose material at the cliff foot which cannot be regarded as a landslide deposits, having fallen from the adjacent cliff face.

\section{LISI JAR LANDSLIDE 131.9-132.1 KM}

The coastline in the vicinity of the landslide shifted landwards by $\sim 40 \mathrm{~m}$ in the western part and by $30 \mathrm{~m}$ at its the centre, at the front of the landslide. In its eastern part, the coastline has moved seawards by tens of metres as a result of coastal protection, via a raised seawall and beach nourishment.

The landslide is located west of the Rozewie headland and is relatively young. The topographic map (Topographische Karte, 1877) shows a bluff coast but without any signs of mass wasting processes (Fig. 3B). We assume that the development of mass movements in this part of the coast is an aftermath of the seawall built in the area of the Rozewie headland. In its present form, this landslide extends over a distance of $\sim 150 \mathrm{~m}$, from the inlet of the Lisi Jar ravine. The total length is $\sim 70 \mathrm{~m}$, while the length of displaced mass is $50 \mathrm{~m}$. The height of the cliff reaches $31 \mathrm{~m}$ a.s.l. and the height of the main scarp reaches $\sim 15 \mathrm{~m}$ (Figs. 4 and 6). The geological structure of the area subjected to landsliding is relatively simple. The upper part of the main scarp is built of tills covered by a thick unit of fine and medium sands. This Pleistocene succession has, in its lower part, a gravel layer. Below this lie fine and medium sands interbedded with clays and silts of Neogene age.

The colluvium can be divided into two parts. The larger (upper) part, the top of which reaches the elevation of $\sim 15 \mathrm{~m}$ a.s.l., is formed of Neogene-Pleistocene deposits. The smaller (lower) part is formed by secondary displacement (with rotation) of the Neogene deposits.

\section{JASTRZĘBIA GÓRA LANDSLIDE 133.8-134.2 KM}

The coastline in the vicinity of this landslide has shifted landwards by $\sim 50 \mathrm{~m}$ in the west and by $20 \mathrm{~m}$ in the east. The land retreat in front of the landslide is $\sim 20 \mathrm{~m}$ (Fig. 3C).

The landslide at Jastrzębia Góra, at western part of the coastal cliff, has been a training ground for studies of lithodynamic processes and slope stability for many years (Subotowicz, 1982, 1995a, 1995b; Kramarska et al., 2011; Kamiński et al., 2012) and is the best recognized landslide in this area, not only due to many archival materials, but especially to the possibility of monitoring the development of mass movements from the moment of its restoration in 2002. Analysis of historical data shows pronounced activity of the cliff. The landslide in its present form extends over a distance of $\sim 350 \mathrm{~m}$. The total length is $\sim 90 \mathrm{~m}$, while the length of displaced mass is $70 \mathrm{~m}$. The height of the cliff reaches $32 \mathrm{~m}$ a.s.l. and the height of the main scarp is $\sim 5-10 \mathrm{~m}$ (Figs. 4 and 7 ). The presence of groundwater within the colluvium was documented in many places. The geological structure of the cliff is constrained by numerous 

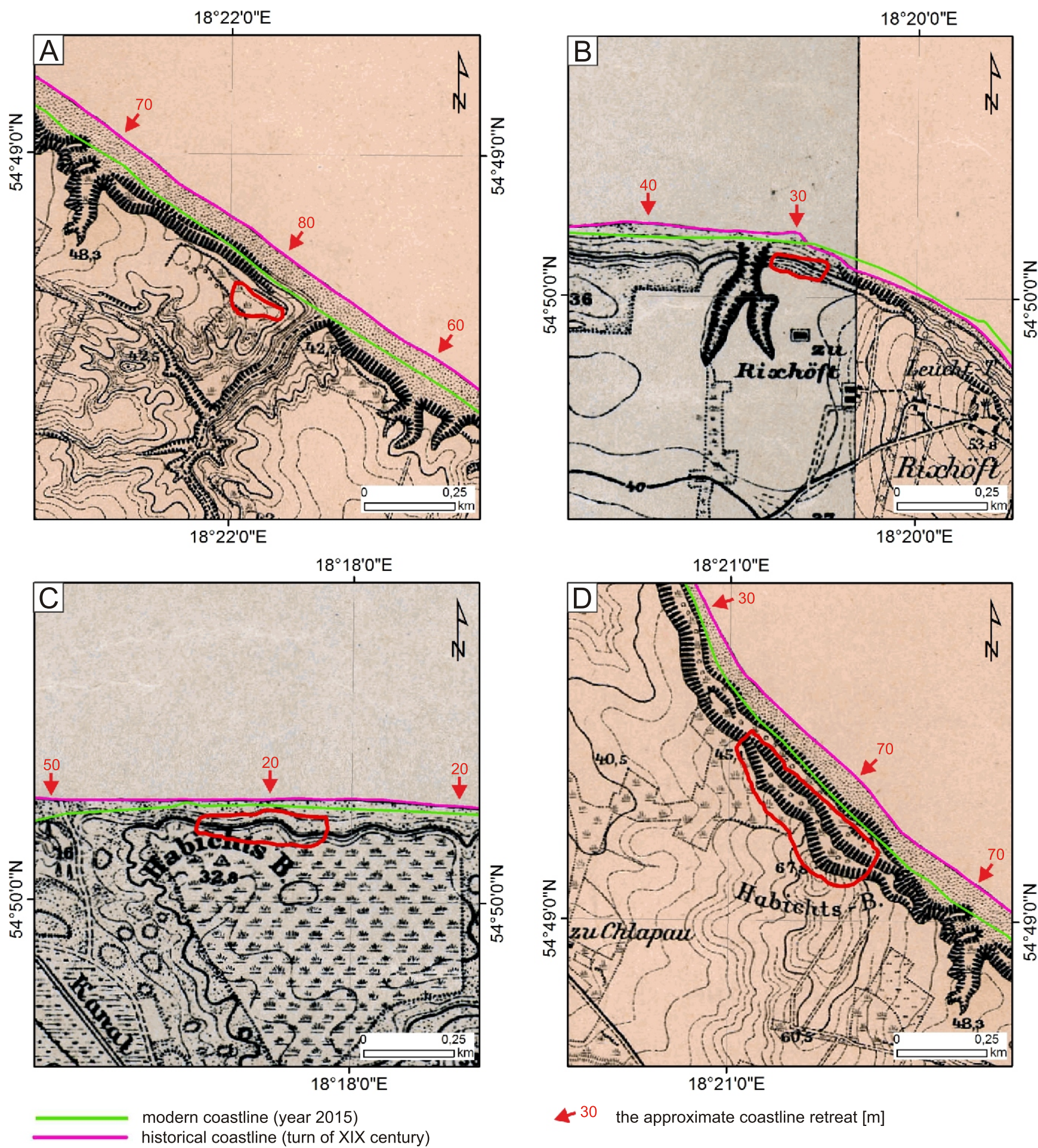

$\leftarrow 30$ the approximate coastline retreat [m]

Fig. 3. Present boundaries of the landslides under discussion and position of the coastline (modern and historical) compared with historical topographic maps (Topographische Karte, 1877, 1910: 137-Ostrau; 138-Rixhof)

A - landslide 128.3-128.5 km "Rudnik"; B - landslide 131.9-132.1 km "Lisi Jar"; C - landslide 133.8-134.2 km "Jastrzębia Góra"; D - landslide 129.4-129.9 km "Pod Radarem" 

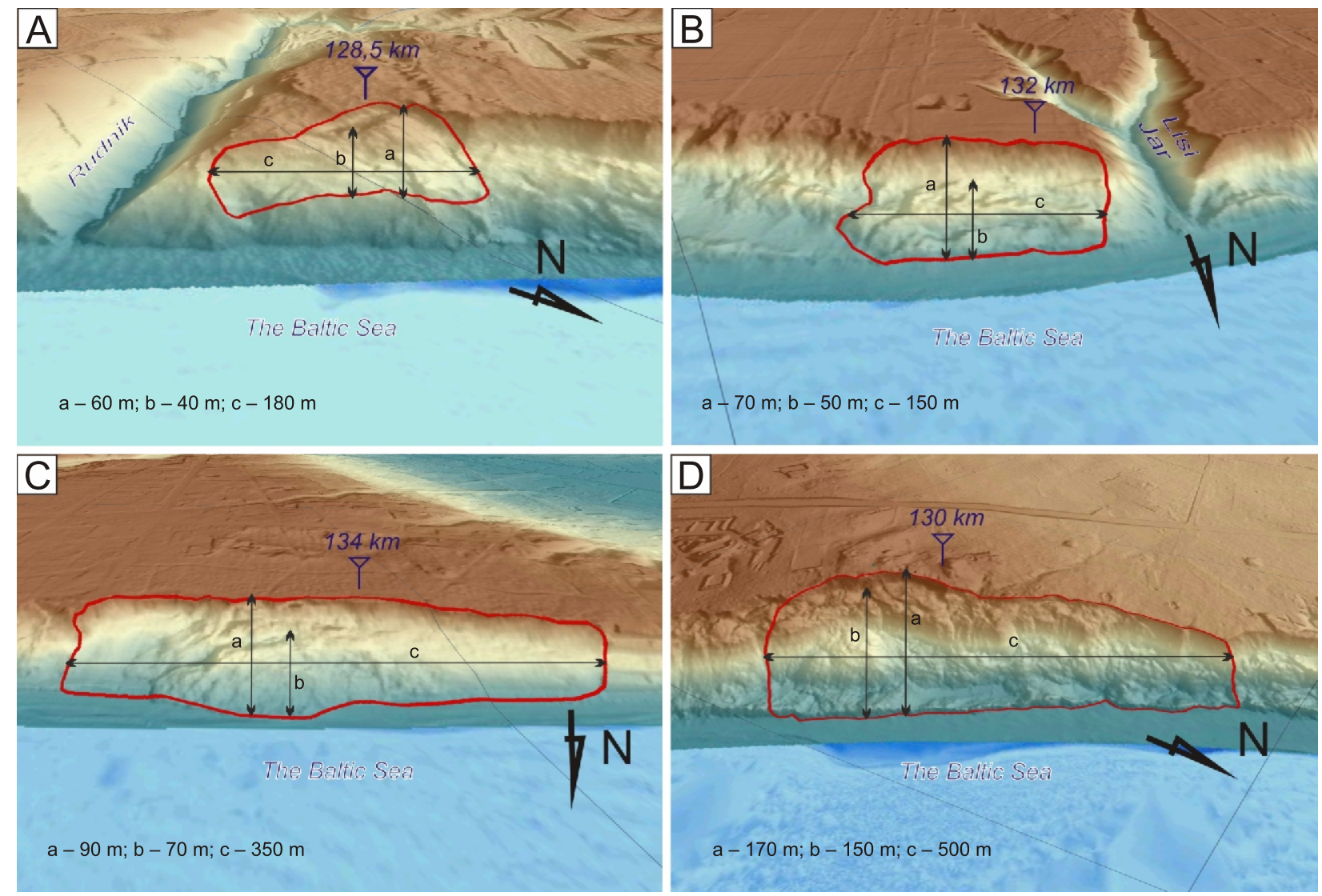

Fig. 4. The digital elevation model (orthogonal view) and the basic parameters of landslides

A - landslide 128.3-128.5 km "Rudnik"; B - landslide 131.9-132.1 km "Lisi Jar"; C - landslide 133.8-134.2 km "Jastrzębia Góra"; D - landslide 129.4-129.9 km "Pod Radarem"; a - total length, b - length of displaced mass, c - width of displaced mass

\section{$S$}

[m a.s.I.]

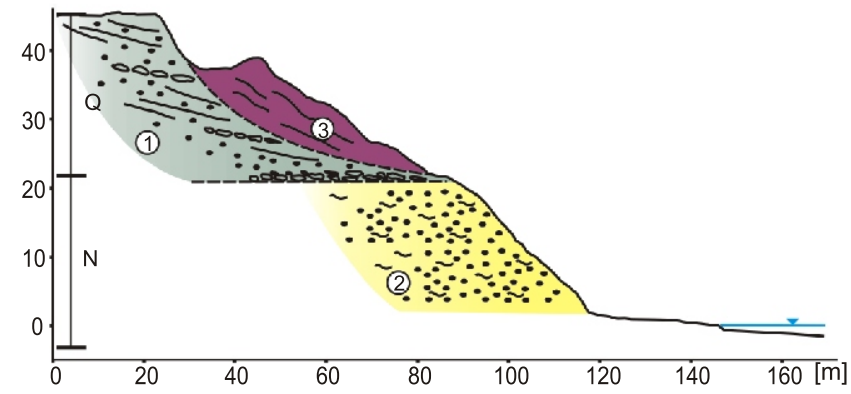

Fig. 5. Illustration of the landslide 128.3-128.5 km "Rudnik", geological cross-section

1 - sand and gravel (with boulders in the lower part); 2 - sand interbedded with mud and clay; 3 - colluvium Q

boreholes, both in the broad and the immediate vicinity of the cliff edge and colluvium. Conditions within the landslide are complex, with alternating cohesive and non-cohesive rocks which are glacitectonically disturbed in the western part. The situation is further complicated due to the presence of discontinuous levels of groundwater, the depth of which varies (Lidzbarski and Tarnawska, 2015). The emergence and considerable activity of the landslide under discussion is caused especially by the geological and hydrogeological conditions, including the presence of water-rich cohesive sediments (Fig. 8), with limited impact of marine erosion affecting the colluvium. In
$S$

[m a.s.I.]

N

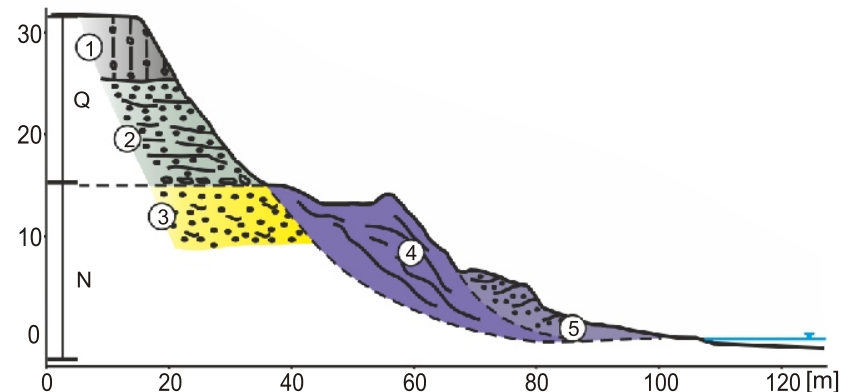

Fig. 6. Illustration of the landslide 131.9-132.1 km "Lisi Jar", geological cross-section

1 - sandy till; 2 - fine and medium sand (with gravel in the lower part); 3 - fine and medium sand (with gravel in the lower part); 4 - colluvium $\mathrm{Q}+\mathrm{N} ; 5$ - colluvium $\mathrm{N}$

2002, the foot of the cliff was protected by a seawall, meant to limit the impact of marine erosion. The seawall does reduce the impact of waves on the cliff, but it negatively affected the offshore (sea-floor). Colluvium erosion takes place only in the moments when it overlaps the seawall. Simultaneously the seawall is a barrier for the sediments from the cliff which are a source of the uppermost mobile layer of the seabed. This situation may contribute to the erosion of the offshore area, and consequently affect the cliff stability. 
$S$

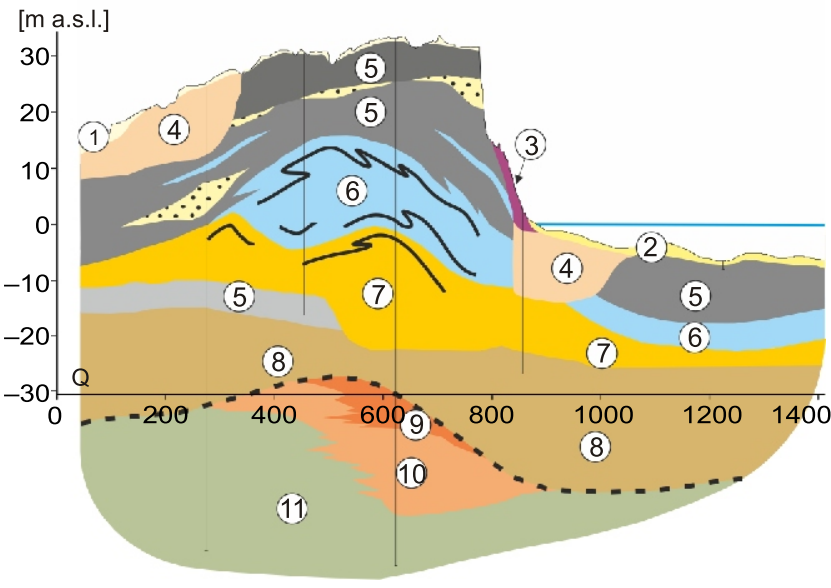

Fig. 7. Illustration of the landslide 133.8-134.2 km "Jastrzębia Góra", geological cross-section

1 - aeolian sand; 2 - marine sand; 3 - colluvium; 4 - fine sand (glaciofluvial); 5 - till; 6 - mud and clay (glaciotectonically deformed); 7 - sand and gravel (glaciofluvial?); 8 - sand (glacial); 9 sand, mud, clay; 10 - sand and gravel; 11 - fine sand with glauconite

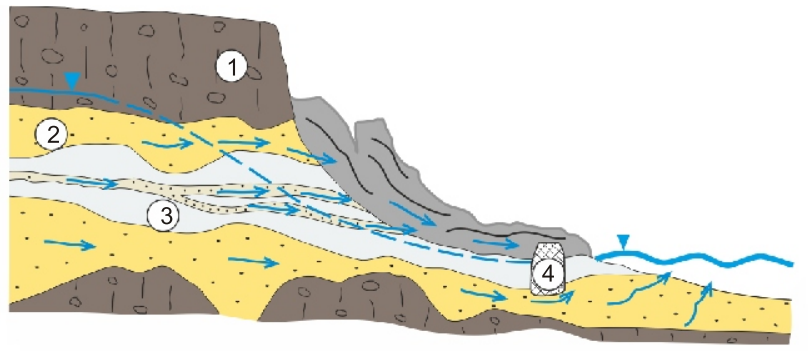

Fig. 8. Simplified diagram of geological and hydrogeological conditions within the Jastrzębia Góra landslide

1 - till; 2 - sand and gravel; 3 - mud and clay; 4 - seawall; arrows - direction of water flow

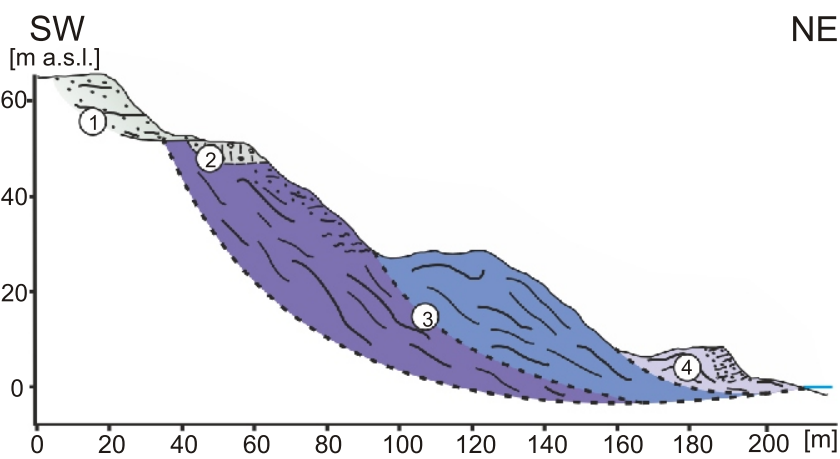

Fig. 9. Diagram of the landslide $129.4-129.9 \mathrm{~km}$ "Pod Radarem", geological cross-section

1 - sand; 2 - till; 3 - colluvium $\mathrm{Q}+\mathrm{N}$ ?; 4 - colluvium $\mathrm{N}$
POD RADAREM LANDSLIDE 129.4-129.9 KM

The coastline in the vicinity of the landslide shifted landwards by $\sim 30 \mathrm{~m}$ in the west and by $70 \mathrm{~m}$ in the east. Retreat of the land in front of the landslide is $\sim 70 \mathrm{~m}$. The group of landslides (south-east of the Rozewie headland) is visible on the oldest analysed topographic maps (Fig. 3D), extending over a distance of $500 \mathrm{~m}$. The total length is $\sim 170 \mathrm{~m}$, while the length of displaced mass is $150 \mathrm{~m}$. The cliff height in this area is up to $60 \mathrm{~m}$ a.s.l. (Figs. 4 and 9) and the height of the main scarp is $\sim 12 \mathrm{~m}$. A characteristic feature of this landslide is the occurrence of morphological steps which may be a consequence of the cliff height and of the lithological properties of the strata building the area of landsliding. The slope of the cliff is formed of 2-3 and locally of 4 steps (Fig. 10). The geological structure within the area of landsliding is difficult to recognize. The geological description was made only at general level due to the large extent of the colluvium and the moderate activity of the landslide, which is overgrown by vegetation. However, in the upper part of the landslide the thick succession of sand and gravel interbedded with clay/silt deposits and a succession of glacial till (revealed at the elevation of $\sim 20 \mathrm{~m}$ a.s.l.) can be observed. These interbeds of clastic deposits are a zone of outflow of water accumulating within the colluvium. Nevertheless we infer that the layers of cohesive deposits are discontinuous. The main part of the colluvium comprises deposits of Pleistocene and Neogene age. The lowermost part of the colluvium, which reaches several metres a.s.I. is built of sand, silt and clay of Miocene age.

\section{DISCUSSION}

The various landslides studied are at various stages of their evolution depending on their geological structure and morphology. In the case of the landslides from by the ravines of Rudnik and Lisi Jar (128.3-128.5 km; 131.9-132.1 km) there occur the same processes but at different stages of development. The starting point for this type of landslide is a relatively stable cliff, where gravitational movements may occur, but without substantial evidence indicating the existence of earlier mass movements. In such conditions the initial movement starts at the cliff top (built of Pleistocene deposits) and reaches the boundary of the Pleistocene/Neogene deposits. It affects poorly lithified deposits, but without affecting underlying, Neogene strata (vide the Rudnik landslide). The Neogene deposits are more cohesive than the Pleistocene ones, so their vulnerability to sliding and water infiltration are lesser. Such state is especially visible during increased storm surge periods when the lower parts of cliff become nearly vertical. Next, increased infiltration of rainwater into the initial colluvium and underlying rocks of the Miocene age may occur. These rocks are characterized by a higher level of diagenesis than the Pleistocene deposits. Such conditions combined with marine erosion destabilize the foot of the cliff and lead to the development of the landslide proper that covers the whole slope (Fig. 11).

The presence of groundwater in the upper part of the main scarp is also significant. In the case of "Lisi Jar" landslide there was a well close by the cliff ( $\sim 60 \mathrm{~m}$ from the cliff edge) which was used for water supply to the nearby resort. The well depth was rather small $(15 \mathrm{~m})$ and collected water stored in the sandy interbeds of the till. Despite the low yield of the well, its use showed the presence of perched water in the cliff, as in the case of the landslides at Jastrzębia Góra (see below). The landslide (Lisi Jar) is stable at present. However, taking into account the height of the main scarp and the amount of colluvial material 


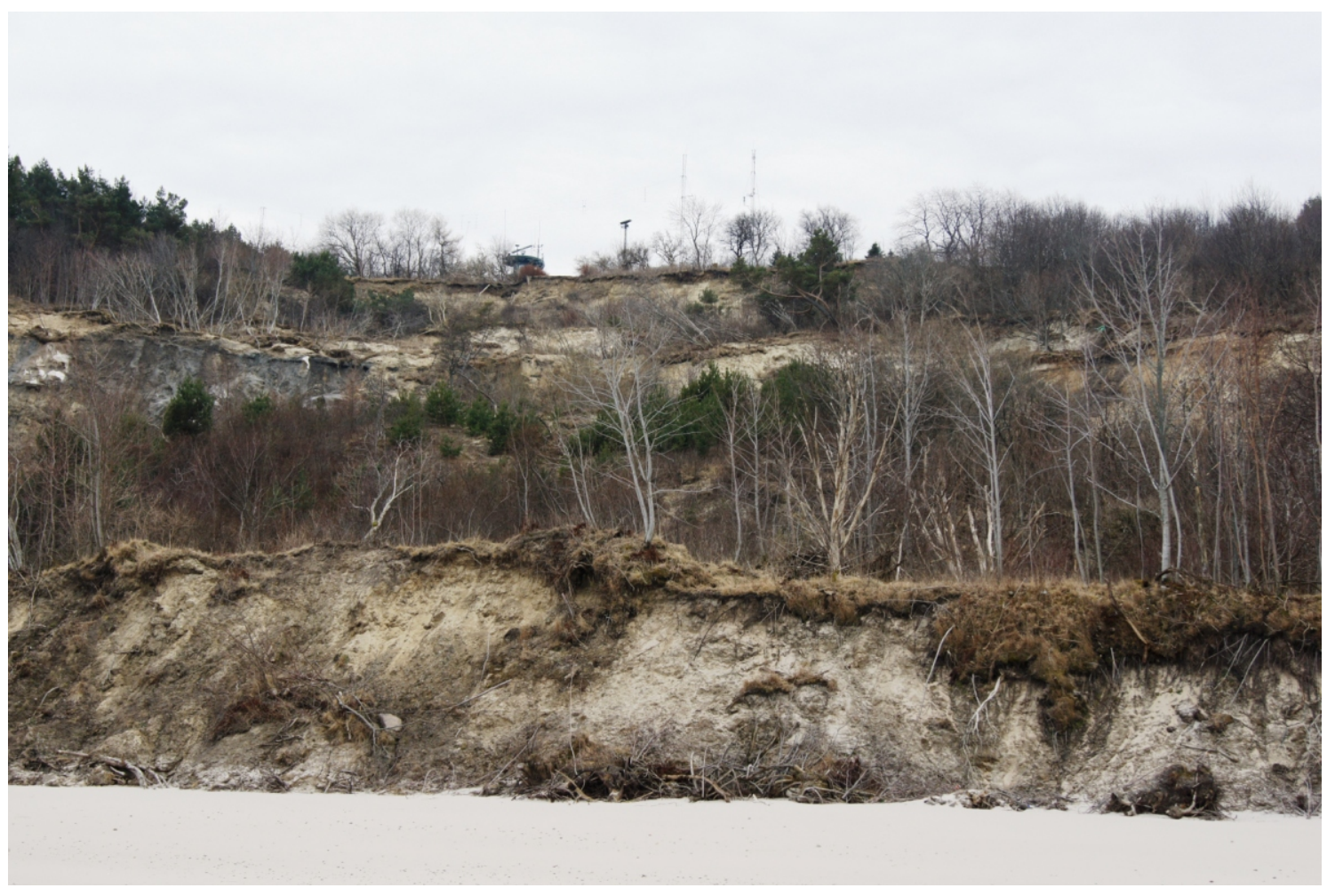

Fig. 10. Photo illustrating the "steps" within the landslide

that is successively eroded by marine action the threshold of stability will be crossed and a renewal of mass movements is expected.

In the complex landslides, the processes are diverse and more complicated. A good example is the Jastrzębia Góra landslide the development of which could be observed from the period starting with cliff stabilization in 2002 to the present. During the first stage, cracks and displacements appeared around the central part of the slope. Then, there was a rotational displacement of the initial colluvium. The constant movement of colluvial deposits led to the destabilization of the main scarp, which consequently led to a significant retreat of the cliff edge. At the moment the landslide is in a temporary state of equilibrium (with slight displacements of the main scarp edge); however, displacements affecting the colluvium continue (Fig. 12). The landslide under discussion is decidedly complex, in which the movement and displacement of sedimentary masses occurs under complex geological and hydrogeological conditions. The situation is further complicated by the seawall raised in 2000 which protects the cliff foot. The construction is meant to protect the cliff and landslide against marine erosion. Yet, erosion of the seabed in front of the seawall occurs because of a lack of thick sandy deposits of the protective layer (Uścinowicz et al., 2014).

The geological structure in the vicinity of the landslide "Pod Radarem" is relatively simple, and the cause of the extensive landsliding here may be interpreted by analogy with the landslide at Jastrzębia Góra, as regards the occurrence of glaciotectonic deformation zones or thrust zones. Such morphogenetic development can be facillitated by at least two factors. Firstly, the topographic situation links the landslide with the natural elevation of the ground surface (the highest part of cliff - the alleged push moraine) above the surrounding generally flat morainic upland. Secondly, the complicated and ambiguous offshore geological situation, where outcrops of sand, silt and brown coal of the Neogene age can be found a few hun- dred metres from the coastline (Kramarska, 1999; Zachowicz et al., 2007). Such morphological and geological configuration may suggest the presence of a thrust/deformation zone that causes increased mass wasting activity.

The development of mass wasting is influenced by a variety of factors which should be considered collectively. Therefore, it is important to determine the "weight" of each factor in relation to the development of these landslides (Table 1).

With regard to the simple landslides, where the geological structure is well-defined, as established by numerous studies (geological and landslide mapping), the relative importance of these factors is simple. The main factor is the effect of recent sea-level rise and storm surges causing marine erosion of the cliff foot. Coastal erosion and shoreline retreat, as shown (e.g., Fig. 3), forms part of the general trend of change on the Polish coast and is intensified during autumn-winter storms (Rotnicki et al., 1995; Łabuz and Kowalewska-Kalkowska, 2011). Thus the removal of talus or colluvial material and direct exposure of the cliff foot to wave attack causes destabilization of the entire cliff. Here we can assign a second-order factor, which is the geological structure. The first displacement occurs in deposits of low degree of diagenesis (of Pleistocene age) which causes faster inflow of rainwater into the lower parts of the cliff (a third-order factor) and, consequently, its activation. The whole sequence is closed (or starts again) with marine abrasion.

The situation of the complex landslides is somewhat different in this context. The cliff slope reaching the limit of equilibrium is subject to transformation, in which the primary role is played by the complex geological conditions. Their negative effects are intensified by the complicated hydrogeological situation (Uścinowicz et al., 2014; Lidzbarski and Tarnawska, 2015). Colluvium displacement is of rotational or rotation-with-flow character, which is caused by a constant inflow of rainwater and groundwater. Human influence is an open question. While in the case of the Jastrzębia Góra landslide it cannot be excluded, 


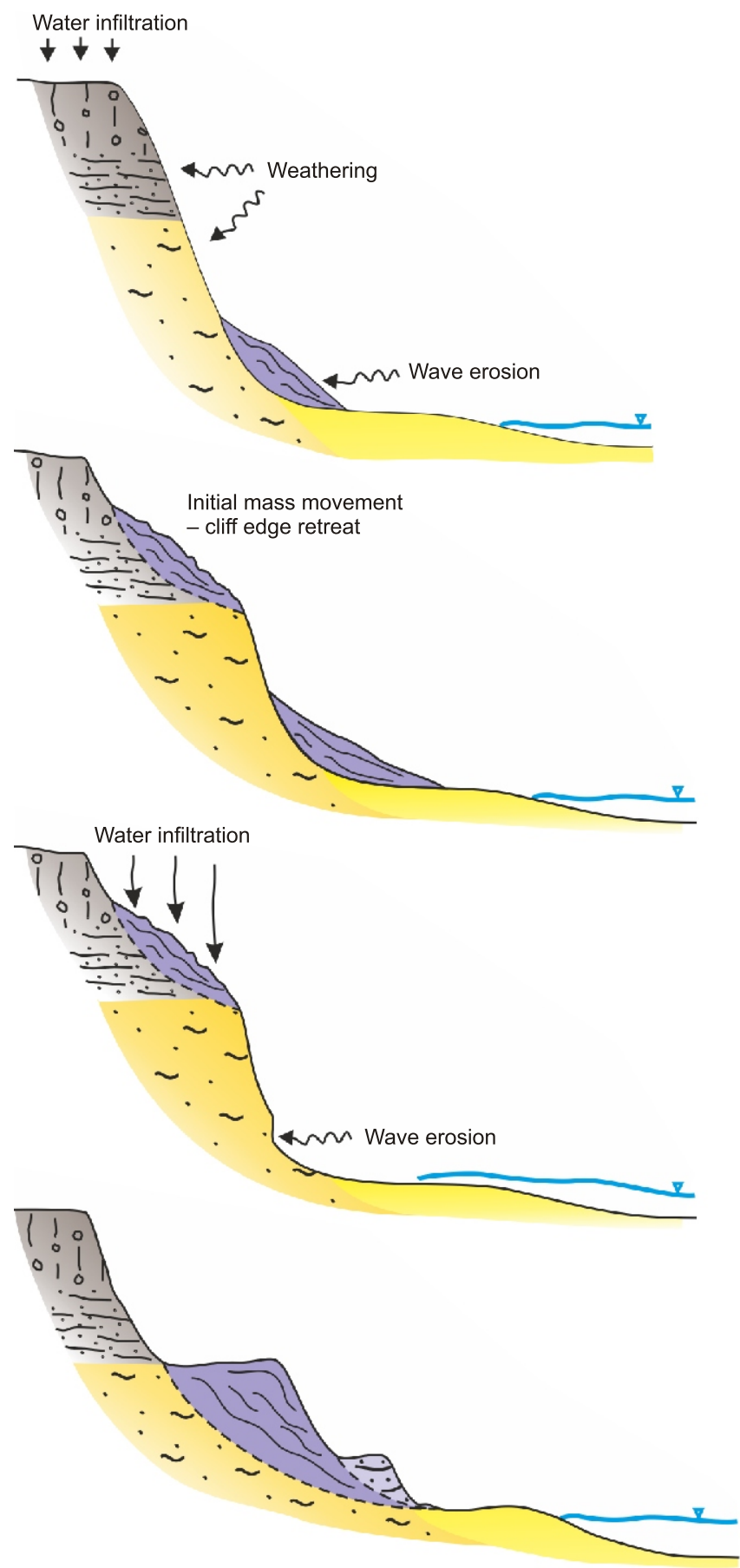

Fig. 11. The stages of development of simple landslides

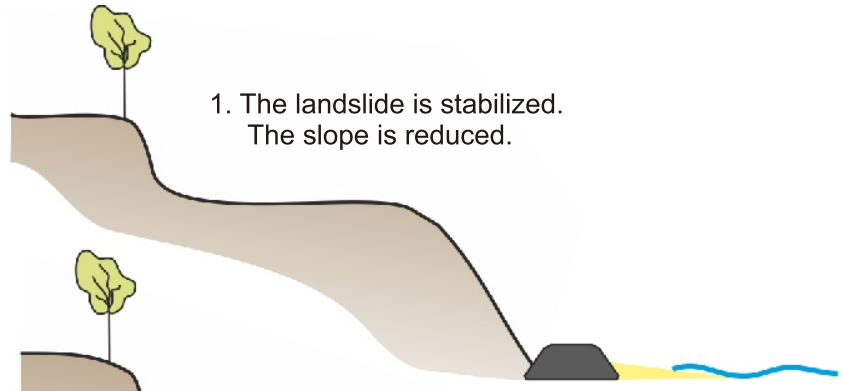

2. The first cracks appear

The rainwater infiltrates into the ground.

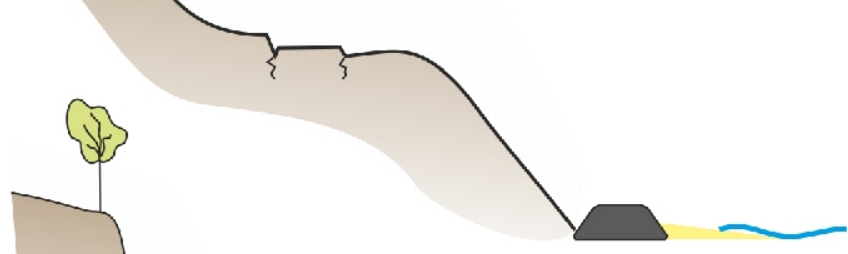

3. Rotational movement of colluvium begins

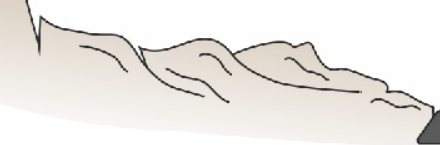

4. The main scarp starts to retreat as a result of colluvial movement

Colluvium material reaches and overlaps the seawall.
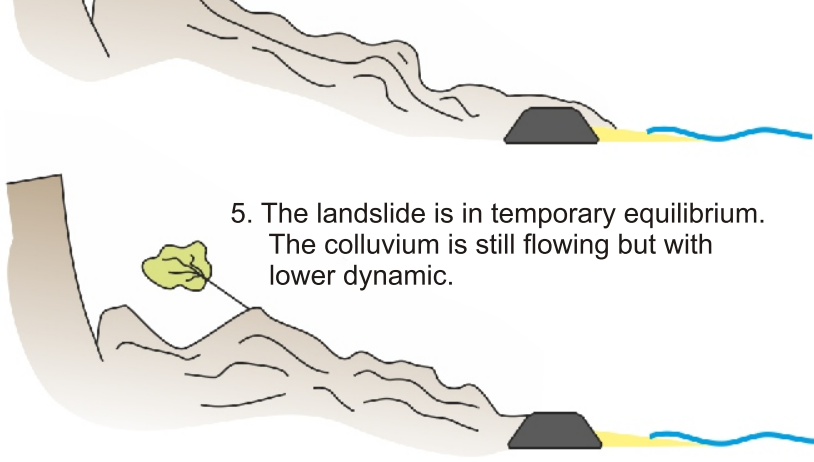

Fig. 12. The stages of development of the Jastrzębia Góra complex landslide

Table 1

The importance of individual factors causing mass movements in relation to simple and complex landslides

\begin{tabular}{|c|c|c|}
\hline & Simple landslide & Complex landslide \\
\hline I & Marine erosion & Geological conditions \\
\hline II & Geological conditions & Hydrogeological conditions \\
\hline III & Weather and hydrologic conditions & Man-made factors \\
\hline IV & - & Marine erosion \\
\hline
\end{tabular}


since the landslide is located close to the urban area and to coastal protection constructions, the "Pod Radarem" landslide is not directly affected by such significant human pressure. Nevertheless, an anthropogenic factor should be considered, at least potentially. It is reflected in the many forms of coastal protection, which often bring unexpected results. In large, complex landslides, marine erosion is less important than in the case of simple landslides. A noteworthy example is the Jastrzębia Góra landslide where mass wasting processes intensified despite construction stopping of marine erosion.

Unlithified, relatively soft rocks and rocks with low levels of diagenesis which are affected by sea-level rise, storm surges and human pressure occur along the major part of the southern Baltic coasts, from Estonia in the north-east to Wolin Island and further to the west (Eberhards et al., 2006; Orviku et al., 2013; Ostrowski et al., 2014; Kenzler et al., 2015; Kostrzewski et al. 2015). The cliff under discussion is characterized by the greatest complexity of geological structure on the Polish coast, both laterally and vertically. At the same time, it has been poorly understood in terms of mass wasting factors. Nevertheless, the results obtained can form a comparative example not only in the Baltic Sea region but also in the regions where soft sediment cliffs dominate. Similar processes have been described on the eastern Canadian coast, where the cliff is composed of glacio-isostatically raised, unconsolidated Late Quaternary marine deposits (Joyal et al., 2016), and along the southern California sea cliffs (USA) consisting of Eocene, cemented claystone and sandstone and Pleistocene, weakly cemented fine-grained sandy deposits (Young et al., 2009, 2016). The examples described clearly show that processes involved within unconsolidated sedimentary cliffs are both universal and include regional nuances that shed new light on bluff coast erosion and geodynamic development.

\section{CONCLUSIONS}

Several years of studies of the cliff coast between Władysławowo and Jastrzębia Góra and the comparative analysis of maps has led to the following conclusions:

1. This area is characterized by unconsolidated deposits of Neogene, Pleistocene and (to a lesser extent) Holocene age.
2. Landslides of various origin, extent and activity are permanently developed within these deposits.

3. At least two types of landslides characterized by diverse geological structure and different stages of development can be distinguished.

4. Simple landslides - developed in homogeneous and undisturbed deposits (e.g. silts, clays, sands) are represented by the forms described along sections $128.3-128.5 \mathrm{~km}$ and $131.9-132.1 \mathrm{~km}$. These landslides are characterized by relatively simple geological structure, with marine erosion as a main factor of their origin.

5. Complex landslides, represented by the forms described in sections $129.4-129.9 \mathrm{~km}$ and $133.8-134.2 \mathrm{~km}$, are characterized by complex geological structure associated with zones of glaciotectonic deformation and by a multi-stage scheme of development.

6. In relation to all of the above types, the prediction of their formation is extremely difficult. Even with long-term observations, the movement of these sediment masses is variable over time and difficult to interpret. Long-term observation (both historical and modern) shows that the changes are continuous, though occurring with varying intensity. The identification of the type of mass wasting movement is crucial in the selection of proper methods of cliff and shore protection.

7. This study of landslides indicates directions for further research, including the need of developing the methodology, which, in addition to providing standard geological information, will identify the location and nature of the slip surface. It seems particularly important to know the impact of groundwater flow in the area of drainage on cliff stability.

Acknowledgements. The authors are grateful to A. Kont and an anonymous reviewer for valuable remarks and suggestions that allowed improving the manuscript. The authors would also like thank to all those who kindly helped during the studies and in the preparation of this paper. The studies were funded by the National Fund of Environmental Protection and Water Management (no. 22-1801-1501-00-1).

\section{REFERENCES}

Carpenter, N.E., Dickson, M.E., Walkden, M.J.A., Nicholls, R.J., Powrie W., 2014. Effects of varied lithology on soft-cliff recession rates. Marine Geology, 354: 40-52.

Cruden, D.M., Varnes, D.J., 1996. Landslide types and processes. Transportation Research Board Special Report, 247: 36-75.

Della Seta, M., Martino, S., Scarascia Mugnoza, G., 2013. Quaternary sea-level change and slope instability in coastal areas: insights from the Vasto Landslide (Adriatic coast, central Italy). Geomorphology, 201: 462-478.

Dickson, M.E., Walkden, M.J.A., Hall, J.W., 2007. Systemic impacts of climate change on an eroding coastal region over the twenty-first century. Climatic Change, 84: 141-166.

Dikau, R., Schrott, L., 1999. The temporal stability and activity of landslides in Europe with respect to climatic change (TESLEC): main objectives and results. Geomorphology, 30: 1-12.
Eberhards, G., Lapinskis, J., Saltupe, B., 2006. Hurricane Erwin 2005 coastal erosion in Latvia. Baltica, 19: 10-19.

Eurosion, 2004. Living with Coastal Erosion in Europe: Sediment and Space for Sustainability: Major Findings and Policy Recommendations of the EUROSION Project. European Commission, Directorate General Environment.

Fiorillo, F., 2003. Geological features and landslide mechanisms of an unstable coastal slope (Petacciato, Italy). Engineering Geology, 67: 255-267.

Hackney, C., Darby, S.E., Leyland, J., 2013. Modelling the response of soft cliffs to climate change: a statistical, process-response model using accumulated excess energy. Geomorphology, 187: 108-121.

Hungr, O., Leroueil, S., Picarelli, L., 2014. The Varnes classification of landslide types, an update. Landslides, 11: 167-194. 
Ilcewicz-Stefaniuk, D., Czerwiński, T., Koryczan, A., Targosz, P. Stefaniuk, M., 2005. Landslides survey in the northeastern Poland. Polish Geological Institute Special Papers, 20: 67-73.

Joyal, G., Lajeunesse, P., Morissette, A., Bernatchez, P., 2016. Influence of lithostratigraphy on the retreat of an unconsolidated sedimentary coastal cliff (St. Lawrence estuary, eastern Canada). Earth Surface Processes and Landforms, 41: 1055-1072.

Kamiński, M., Krawczyk, M., Zientara, P., 2012. Recognition of geological structure of the Jastrzębia Góra cliff using resistivity tomography methods for landslide hazard (in Polish with English summary). Biuletyn Państwowego Instytutu Geologicznego, 452: 119-130.

Kenzler, M., Tsukamoto, S., Meng, S., Thiel, C., Frechen, M. Hüneke, H., 2015. Luminescence dating of Weichselian interstadial sediments from the German Baltic Sea coast. Quaternary Geochronology, 30: 251-256.

Kostrzewski, A., Zwoliński, Z., Winowski, M., Tylkowski, J., Samołyk, M., 2015. Cliff top recession rate and cliff hazards for the sea coast of Wolin Island (Southern Baltic). Baltica, 28 : 109-120.

Kramarska, R., 1999. Trzeciorzęd strefy brzegowej Bałtyku na odcinku Władysławowo - Jastrzębia Góra. Posiedzenia Naukowe Państwowego Instytutu Geologicznego, 55: 165-166.

Kramarska, R., Frydel, J., Jegliński, W., 2011. Terrestrial laser scanning application for costal geodynamice assesment: the case of Jastrzębia Góra Cliff (in Polish with English summary) Biuletyn Państwowego Instytutu Geologicznego, 446: 101-108.

Kuhn, D., Prufer, S., 2014. Coastal cliff monitoring and analysis of mass wasting processes with the application of terrestrial laser scanning: a case study of Rügen, Germany. Geomorphology, 213: 153-165.

Lari, S., Frattini, P., Crosta, G.B., 2014. A probabilistic approach for landslide hazard analysis. Engineering Geology, 182 (part A): 3-14.

Lee, E.M., 2008. Coastal cliff behaviour: observations on the relationship between beach levels and recession rates. Geomorphology, 101: 558-571.

Lidzbarski, M., Tarnawska, E., 2015. The role of the hydrogeological research on cliff coast in diagnosis and foracasting of the geological hazards (in Polish with English summary). Przegląd Geologiczny, 63: 901-907.

Łabuz, T.A., Kowalewska-Kalkowska, H., 2011. Coastal erosion caused by the heavy storm surge of November 2004 in the southern Baltic sea. Climate Research, 48: 93-101.

Łęczyński, L., 2002. Morfolitodynamika podbrzeża brzegu klifowego w Jastrzębiej Górze (in Polish). In: Przewodnik LXXIII Zjazdu Polskiego Towarzystwa Geologicznego, Geologia Regionu Gdańskiego (eds. J. Zachowicz and R. Kramarska): 63-66. Polskie Towarzystwo Geologiczne, Państwowy Instytut Geologiczny, Gdańsk.

Masłowska, M., Zaleszkiewicz, L., Olszak, I., Jurys, L., Michałowska, M., 2002. Budowa geologiczna klifu w Jastrzębiej Górze (in Polish). In: Przewodnik LXXIII Zjazdu Polskiego Towarzystwa Geologicznego, Geologia Regionu Gdańskiego (eds. J. Zachowicz and R. Kramarska): 59-62. Polskie Towarzystwo Geologiczne, Państwowy Instytut Geologiczny, Gdańsk.

Mickovski, S.B., Santos, O., Ingunza, P.M.D., Bressani, L., 2015. Coastal slope instability in contrasting geoenvironmental conditions. In: Proceedings of the XVI ECSMGE Geotechnical Engineering for Infrastructure and Development (eds. M.G. Winter
D.M. Smith, P.J.L. Eldred and D.G. Toll): 1801-1806. ICE Publishing.

Montoya-Montes, I., Rodriguez-Santalla, I., Sanchez-Garcia M.J., Alcantara-Carrio, J., Martinez-Velazquez, S., Gomes-Ortiz, D., Martin-Crespo, T., 2012. Mapping of landslide susceptibility of coastal cliffs: the Mont-Roig del Camp case study. Geologica Acta, 10: 439-455.

Orviku, K., Tõnisson, H., Kont, A., Suuroja, S. and Anderson, A. 2013. Retreat rate of cliffs and scarps with different geological properties in various locations along the Estonian coast. Journal of Coastal Research, Special Issue, 65: 552-557.

Ostrowski, R., Pruszak Z., Babakov A., 2014. Condition of South-Eastern Baltic Sea shores and methods of protecting them. Archives of Hydro-Engineering and Environmental Mechanics, 61: 17-37

Pellicani, R., Van Westen, C.J., Spilotro, G., 2013. Assessing landslide exposure in areas with limited landslide information. Landslides, 11: 463-480.

Rotnicki, K., Borówka, R.K., Devine, N., 1995. Accelerated sea level rise as a threat to the Polish coastal zone quantification of risk. Journal of Coastal Research, 22: 111-134.

Subotowicz, W., 1982. Litodynamika brzegów klifowych wybrzeża Polski. GTN - Ossolineum, Wrocław.

Subotowicz, W., 1995a. Transformation of the cliff coast in Poland. Journal of Coastal Research, 22: 57-62.

Subotowicz, W., 1995b. Transformation of the cliff coast in Poland. Prace Państwowego Instytutu Geologicznego, 149: 212-214.

Topographische Karte, 1877. Maßstab 1:25,000, Sect.: 137-Ostrau. Staatsbibliothek zu Berlin.

Topographische Karte, 1910. Maßstab 1:25,000, Sect.: 138-Rixhof. Staatsbibliothek zu Berlin.

Uścinowicz, Sz., Zachowicz, J., Graniczny, M., Dobracki, R., 2004. Geological structure of the southern Baltic coast and related hazards. Polish Geological Institute Special Papers, 15: 61-68.

Uścinowicz, G., Kramarska, R., Kaulbarsz, D., Jurys, L., Frydel, J., Przezdziecki, P., Jegliński, W., 2014. Baltic Sea coastal erosion; a case study from the Jastrzębia Góra region. Geologos, 20: 259-268.

Wagner, M., 2007. The Miocene coal deposits from the Kępa Swarzewska at the Baltic Seaside (in Polish with English summary). Kwartalnik AGH Geologia, 33: 69-88.

Varnes, D.J., 1978. Slope movement types and processes. Transportation Research Board, Special Report, 176: 11-33.

Young, A.P., Flick, R.E., Gutierrez R., Guza R.T., 2009. Comparison of short-term seacliff retreat measurement methods in Del Mar, California. Geomorphology, 112: 318-323.

Young, A.P., Flick, R.E., O'Reilly, W.C., Chadwick, D.B., Crampton, W.C., Helly, J.J., 2014. Estimating cliff retreat in southern California considering sea level rise using a sand balance approach. Marine Geology, 348: 15-26.

Young, A.P., Guza, R.T., O'Reilly, W.C., Burvingt, O., Flick, R.E., 2016. Observations of coastal cliff base waves, sand levels, and cliff top shaking. Earth Surface Processes and Landforms, 41: 1564-1573.

Zachowicz, J., Uścinowicz, Sz., Jegliński, W., Zaleszkiewicz, L., 2007. Mapa geodynamiczna polskiej strefy brzegowej Bałtyku południowego w skali 1:10 000, ark. Karwia, Jastrzębia Góra-Rozewie z objaśnieniami (in Polish). Państwowy Instytut Geologiczny, Warszawa-Gdańsk. 